\title{
THE MARKETING STRATEGY OF MADURA TOURISM INDUSTRY AREA TROUGH SUSTAINABLE DEVELOPMENT BASED GENDER
}

\author{
Mohammad Taqiuddin Mohammad \\ Universiti Malaya \\ Email : m.taqiuddin@um.edu.my \\ Abd.Hannan \\ Islamic Institute of Madura \\ Email : Hannan.tufiqi@gmail.com \\ Alan Suud Maadi \\ Universiti Malaya \\ Email : alansuudmaadi@yahoo.com
}

ARTICLE HISTORY

Received:

28 June 2019

Accepted:

28 June 2019

Online available:

30 June 2019

Keywords:

Marketing area,

Madura tourism,

sustainable

development,

Gender.

\section{ABSTRACT}

Being declared in 2015 in Rio De Janeiro, Brazil, sustainable development goals (SDGs) has an aim to answer various humanitarian-environment crisis of millennium era (MDGs). One of the main problems which become a focus is woman's participation. Especially in development context, whether in international, national, or local scope. This paper entitle, The Marketing Strategy of Madura Tourism Industry Area trough Sustainable Development Based Gender.In particular, this study has an aim to analyze the existential of Madura woman, dealing with the area development based SDGs. Various crucial issues which become a focus of this study namely; the dynamic Madura tourism industry, sustainable development concept, and development idea based gender. The three crucial issues above will be elaborated based on the three research problems below: 1). How is the existence of Madura tourism? 2).Whatis the definition of sustainable development? 3). How is the position of gender plays a role and strategic function in marketing activity of Madura tourism industry for the next? This study is qualitative method. The data of this paper is from two sources namely primary and secondary data. The theory perspective of this study is using area marketing theory of Richard Florida and Femenis George Ritzer theory. In general, this paper has an aim to describe how the dynamic Madura tourism industry 
is, this study has big contribution in offering the Madura development idea, especially in promoting the local industry area to sustainable development area carrying the spirit of equality.

Kata Kunci:

Marketing area, Pariwisata

Madura, Sustainable development, Gender.

\section{ABSTRAK}

Dideklarasikan pada tahun 2015 di Rio De Janeiro, Brasil, tujuan pembangunan berkelanjutan (SDGs) adalah untuk menjawab berbagai krisis kemanusiaan-lingkungan di era milenium (MDGs). Salah satu masalah utama yang menjadi fokus adalah partisipasi perempuan. Terutama dalam konteks pembangunan, baik dalam lingkup internasional, nasional, atau lokal. Makalah ini berjudul, Strategi Pemasaran Kawasan Industri Pariwisata Madura berdasarkan Jenis Kelamin Berbasis Pembangunan Berkelanjutan. Penelitian ini memiliki tujuan untuk menganalisis keberadaan perempuan Madura, berurusan dengan pengembangan wilayah berbasis SDGs. Berbagai isu krusial yang menjadi fokus penelitian ini yaitu; industri pariwisata Madura yang dinamis, konsep pembangunan berkelanjutan, dan gender berbasis ide pembangunan. Permasalahan penelitian di bawah ini: 1). Bagaimana keberadaan pariwisata Madura? 2). Apa definisi pembangunan berkelanjutan? 3). Bagaimana posisi gender memainkan peran dan fungsi strategis dalam kegiatan pemasaran industri pariwisata Madura untuk selanjutnya? Penelitian ini adalah metode kualitatif. Data tulisan ini berasal dari dua sumber yaitu data primer dan sekunder. Perspektif teori dari penelitian ini adalah menggunakan teori pemasaran area dari Richard Florida dan teori Femenis George Ritzer. Makalah ini memiliki tujuan untuk menggambarkan bagaimana dinamika industri pariwisata Madura, studi ini memiliki kontribusi besar dalam menawarkan ide pengembangan Madura, terutama dalam mempromosikan kawasan industri lokal ke area pembangunan berkelanjutan yang membawa semangat kesetaraan.

\section{INTRODUCTION}

In recent years, the term of sustainable deployment become one of successful development issues attracted much attention (Rahadian, 2016:47). The countries in the world united in the United Nations strive maximally to align the development vision of 
their countries by development plane of sustainable development goals. Seemingly, they have trust that sustainable development goals era is the precise momentum to confirm the progress of their countries. Some of confirmation efforts development is promoting the industry in tourism sector collectively and sustainably.

Concerning the big agenda of sustainable development goals, the economic confirmation of country through tourism sector relevant enough.As we know one of 17 work object of sustainable development goals closely related to the innovation industry.The development through innovation industry sector is hinting at the need to create an industrial source and new economic activity which is possible to present solution for improvement, or even improving the standard of living of the community in general. The innovation industry sector which is offered in many innovations including also in the term of tourism, with in certain limits may be the answer to some of the social economic problems which are crowded by factory industry and the exploitation of social nature. In research of World Trade Organization (WTO), ever one from 8 workers in this world of his life depends on the sustainable of tourism (Pintana, 2005: 5).

In Indonesia itself, the optimism of increasing economic aspect through improvement of tourism activities very likely to be achieved. Furthermore, Indonesia is recognized as a thousand islands which consist of beautiful natures, and various unique, special, and native cultures. Whole the properties will drive the strategy economic when they manage intensively, although some problems will be faced.

In this limit, the participation of local government may be one from some problems become an obstacle in tourism improvement in some areas (Surtikanti, 2013: $20)$, in many cases their agenda underwent the problem. Not only local politic policy but also development instrument which doesn't carry a spirit and vision of universality.

Dealing with the universality vision, the tourism development based sustainable pay the attention big enough to discriminative and dominative practice whether from power, wisdom, or particular social status. Namely dealing with gender which include discriminatory practices, the violence of gender and social participation then every social realities dealing with right limit by gender. Whereas, based on the data ofWorld Bank, mentioned that gender equality is a central issue of development that will strengthen the country's capacity to improve. Reducing the poverty and governing effectively. In that context the country achieve advance development. Then, at least have to pay attention to issues related to gender equality (World bank, 2001: 24).

In the context of Indonesia development, including tourism industry sector, the discourse of the gender can't be separated. In many momentums, gender discourse often appears to the surface, whether in violence, limit, lack of freedom even more extreme than that, namely exploitation practice. It proves that the democracy which is believed to be a space of representation of justice and equality gender have been 
opened. But it still has the problem in the practice side. The assumption can be looked from gender discourses, then discriminative and subordinated practices by feminist masculinity (Sutarso, 2011: 4).

If it's observed deeply, gender problems in the development dimension of Indonesia is strong indication, that social problems related to gender is not enough to accomplish structurally. Furthermore, it needs to be balanced by cultural approach. Structurally, actualization of democracy value may become a media of achieving social right of society justly and equally although in some cases have problems, such as the existence of the regulation on women whose emergence without prior communications. So, it is very likely have a negative impact (Bambang, 2004: 187).

Culturally, gender problem can emerge as the local culture is still adjacent by cultural values of gender bias, such as patriarchy, feudalism, and social society relation that upholds the concept of hierarchy (Susanto, 2015: 123). In cultural context, the problem of cultural gender is very likely to hamper development, because often programs and policies that are applied are biased on alignments and enforcement toward particular social participation and gender. The majority of the Madurese population is Muslim, but the application of the basic principles of Islamic teachings concerning equality is very lacking. In the egalitarian principle, equality between humans, both men and women and between nations, tribes, and descendants is hinted at in QS. al-Hujurat: 13.

In this frame of mind, various problem sides which have been blocking the development of Madura Island, verily it can be analyzed by this perspective. That the problem of Madura development is not only structural factor which has related to bureaucracy and government participation but also cultural factor which has related to development system that is not appropriate with spirit of emancipative and equality.

\section{Research Focus}

This paper entitled, The Area Marketing Strategy of Madura Tourism Industry through sustainable development based gender. This study specially has a purpose in terms of studying three main problems. First, the dynamic of Madura development in general.Second, gender issue in Madura development. Third, the area marketing strategy of Madura tourism toward sustainable development oriented gender. Concerning this study, the above three crucial issues will be elaborated by three research focuses below; 1) what is definition of sustainable development? 2) how is the existence of Madura tourism? 3) how is the position of gender plays the role and strategy function in the marketing activities of Madura tourism?

\section{RESEARCH METHOD}


The method of this paper is library method, library method is the method that emphasize the use of literature as the primary data source. This term of literature refers to any scientific study which has relevance with the research focus in this paper (Wirartha, 2006: 150). In this chance, the data through library is focused to three crucial themes; the sustainable development concept, socio-culture of Madura society, and area marketing strategy of Madura tourism.

Obtaining the objective data, the library study in this research is more emphasize the new data, especially from the result of research whether in essay, thesis, dissertation and research journal. Various literatures that conduct the Madura analysis, the development concept in large perspective, the two of them are the strategic theme which will be elaborated in this paper. Reading development, Madura socio-culture, and the improvement dynamic of Madura industry in a broad perspective will make the writing of this paper become more critical and profound.

\section{RESULT AND DISCUSSION}

\section{Development, A Conceptual Reading}

In social knowledge discourse, the definition of development is debatable, until now that definition is still debatable. Almost nothing to definite the development through final concept and idea. It indicates the term of development has close related to social problem and change which not only complex but also dynamic. The development is the representation of society change which lasts continuously. Whether by evolution or revolution.

Etymologically, the development is from develop means the way of arrange or arrangement which is a form; structure. Based on the Indonesiadictionarydevelopment is a process, manner, or a deed to develop (KBBI, 2001: 81). Development is a process of planning to perform which is related to one another, continuous and sustainable. The development as "manner" is to qualify a method or systematic strategy, structured to achieve development object. Accordingly, development in etymology means an activity of develop which is continuously done by strategic, approach manner, or particular appropriate method.

Terminologically, Siagian (1994) as quoted by Ricky Wirawan and his friends (2015) development is an effort of growth and change planed and made consciously by a nation, country, and government toward modernity in the framework of nation's guidance (Wirawan and his friends, 2015: 308). The definition of development in this perspective is to qualify to three things; growth, change, and modernity. The growth concept explain that development is to attend the improvement economically, in order to encourage member to improve whether qualitatively and quantitatively. The change concept is to qualify that development need to attend the reparation to whole life sector that is oriented to modern system structure of society social life. 
In other occasion.Alexander (1994) as quoted by TiraNurFitria (2016) definite the development as the process of change touching whole system and social structure. Whether politic, education, economic, technology, infrastructure system and culture (Fitria, 2016: 30). This definition is like a portes reading (1976), which means that development as economic transformation, social and culture for attending a reparation in every life aspect of society. Deddy T. Tikson (2005) definite development as economic transformation step, social, culture which is done intentionally and planed through the enactment of policies and strategy toward the condition expected (Tikson, 2005: 135).

Conceptually it has many definitions, contextually the development activity has three fundamental themes. The three fundamental themes in development process are; First, coordination, means the development needs to consider the adjustment aspect, balance, and good arrangement (Iwan and R. Dahuri, 2004: 20). Development should not be run at random, development must by process of planning which is really mature, in order that the implementation attend the positive values for society sustainability in general. In this coordination phase, the thing that must be emphasized is object, participation, and the participation of society in general.

Second, the alternatives more occurred validly. Means that the agenda of development have to create and attend two or some possibilities for society, the possibilities are oriented to help and ease them in reaching life service which is not only good but also achievable. (Iwan and R. Dahuri, 2004: 20). This point focuses to spirit of humanism that development has to transform the humanity value which is oriented to problem solving and moral value guidance and religious community etiquette (Iwan and R. Dahuri, 2004: 20). Dealing with global development approach, at least there three development models which is recently implemented by many world countries. The three development models are; 1 ) the modernism development which is based on thinking of WW. Rostow, 2) Modern Millennium development model which is well known called by MDGs, 3) the sustainable development goals model. The last model is an up-to-date product which is being encouraged all over the world including Indonesia.

\section{WW.Rostow and Modernism Development Theory}

In modern era development discourse, development theory of Rostow become one of theories that is famous in the world. Development theory of Rostow, specifically focus on economic development, has inspired for the discourse of world development. This can not be separated from the success of Rostowformulate how the development process can be run. From originally backward countries (traditional) become modern countries. In his theory, Rostow explain that the development will have five evolution phases, namely; 1) the traditional society, 2) the precondition for take-off, 3) the takeoff, 4) drive to maturity, and 5) the age of high mass-consumption. The above five phases 
will occur in multidimensional process, including the characteristic of economic condition change, social, and politic in the country or in the area (Prasetya, 2016: 17).

\section{The traditional society}

In Rostow's development theories, the traditional society is they have economic activities by traditional method whether in production, distribution, and consumption activities. In Rostow's point of view, the society that has the above characteristic is the society that has not improvement in knowledge and technology and has not rational paradigm thinking. In vice versa they more emphasize the traditional production, in the form of custom and tradition which is inherited by his predecessors (Arsyad, 2004: 47). By this traditional way of life, the traditional society has low work productivity level so that it is not competitive to accommodate on large scale. The search system and their lives depend more on the agriculture sector not industry sector.

\section{The preconditions for take-off}

In this phase, Rostow sees the society in transition phase, society optimizes themselves to strengthen and improve their economics. In Rostow's believe, when society has optimized the economic improvement at that time the improvement and change of development will be running well (Hendriyani, 2016: 21).

The main characteristic of this society is the implementation of traditional economic by modern system, such as the use of technology. Furthermore, the economic activity of this society is also supported by infestation activity and the attendance of banking (Restiyanto, 2006: 176). Thus, the development activity in precondition for takeoff phase although consider to knowledge and technology, but never leave the traditional life system. In vice versa there is an appropriate thing which the two of them unite and confirm each other.

\section{The take-off}

The most dominant characteristic in this phase is the success of the country finding the leading economic sector (Pasaribu, without years: 33). The leading economic sector significantly will help and encourage growth rate. So that it will really help to encourage other sectors. Thus, Rostow emphasizes that every area or society must be able to use every properties and nature potential of his area. Furthermore, the existence of human resources including education and mastery of technology is absolute precondition that must be exist.

Dealing with this leading sector, Rostow explains every region has each leading sectors. In this case, Rostow sees the England (1783-1802) can implement the development of take-off phase through leading sector namely textile. French (18301860) has network sector of train road. In Asia, Japan (1878-1900) can implement the take-off phase by leading economic sector of silk. On the plains of Latin, Argentina (1935) 
can implement leading sector of industry of import substitution (Pasaribu, without years: 34). Exactly, the development of leading sector in Rostow's perspective consider to the creation of a modern socio-culture based leading sector of economic potential in each countries.

\section{The drive to maturity}

In particular aspects, the development process that has been in the drive to maturity, has similarity feature with the society of take-off. The similarity in on the massive of using technology as activity instrument of their life (Pasaribu, without years: 34). Anyhow, there have aspect to distinguish between societies of the drive maturity with societies of take-off. Means the way of their mindset in implementing the leading sector.

This society has more leading thinking and modern, produce the leading sector based on their creativity is not only for producing but also producing new commodity. What they call leading sector is not determined by nature prosperity in the country but to a success of them in managing, cultivating, using, and creating some nature resources. Create it become new product which produces economic power (Pasaribu, without years: 34).

\section{The Age of High Mass Consumption}

The age of high mass consumption phase is the last thought of Rostow of society development phase. In this level, the society development is no longer engaged in production and distribution. The cycle development of the country that engaged in production through the industry activity or agriculture is change. Becoming society development which is dominated by high consumptionbehavior(Pasaribu, without years: 35).

On this limit, development problem of modernization is not only uncontrolled consumption pattern of society but also dealing with various social crisis related to injustice and inequality gender. This crisis is in the social scientist, especially the expert of development, conveying the critic and new ideas. Modern development is considered fail in attending the prosperity so that it needs new approach. One of them is by millennium development model called Millennium Development Goals (MDGs).

\section{The Development of Millennium Era (MDGs)}

Historically, the attendance of Millennium era development, MillenniumDevelopment Goals (MDGs).Cannot become an exception from high level conference or Millennium Summit that occurred in the center of united nation in New York, 6-8 September 2000. At that occasion, the leaders of the world, especially the countries that united in the united nation, they agree to formulate the new development 
model for answering and accomplishing various global problems. Their agreement implement the millennium declaration in the united nation, at that time followed by 189 member countries including Indonesia (Syafrawati, 2006: 17)

Dealing with it, the countries that involved as declaratory is willing to implement new global partnership for lacking of poverty which nowadays become scary specter of world countries especially in developing country. This millennium declaration finally recognized by millennium development project then called by Millennium Development Goals (MDGs). Which will take place during the period 2000-2015 (Sulistyo and his friends, 2010: 18).

As a development project, MDGs has 8 objects, namely; 1 ) ending poverty and hunger, 2) universal education, 3) gender equality, 4) children health, 5) mother health, 6) HIV/AIDS prevention, 7) environmental sustainability, and 8) global partnership (Utomo, 2007: 233). The eight development points of MDGs become a bleu print that is agreed by whole countries in the world. Supporting the eight points of MDGs developing countries, such as Indonesia has responsibility to move in the bottom level. Whereas, the advance country such as The United State of America, must support and help toward a success of every purposes and target of MDGs (Sulistyo and his friends, 2010: 18).

In Indonesia itself, as one of the country that sign the millennium development declaration, the MDGs program gives great opportunities and expectation in solving the various problems and social crisis. Even less, Indonesia is as developing country, the global development instrument of MDGs is expected to impact significantly to participate solving some social problems that has not solved well. Encouraging the economic improvement, by lacking the social imbalance. Furthermore, the developing countries such as Indonesia has crucial problem with the equality.

Just the same, in various problem that Indonesia has, such as the rise of act of terror, rising the conflict among the communities, and unstable politic after reformation era 1998, directly implementing the MDGs development find the problem (Sulistyo and his friend, 2010: 18). As a consequence, in general the development MDGs program of Indonesia that is implemented for 2000-2015 find some failures. Because the center government and local government are not cooperative and also the lack of the participation from the private sector or society in the country are various problems which hamper MDGs development in Indonesia. Besides that, the crucial problem is the limited domestic funds, and national instability politic. The various problems must impact the implementation of MDGs development in Indonesia (Sulistyo and his friend, 2010: 19).

\section{Sustainable Development Goals (SDGs)}

The ongoing public hearing of united nation to the 70thin September 2015 in New York, the United State of America become a history in the process of development 
in the world. In this session, there are 193 president and government of the world for agreeing the new development agenda that noted in the document entitled Transforming Our World: the 2030 Agenda For Sustainable Development (Utomo, 2007: 233). The agenda of development produce the agreement then called Sustainable Development Goals (SDGs).

As a form of continuation era of MDGs, the agenda of sustainable development for a spirit of change in creating a better life. It means not only global reality life which is more advance, develop, and transformative, but also the SDGs strive to create the condition of orienting to guarantee the human right. Then the equality to encourage social development, economic and environmental life which is orienting to achieve life prosperity (Erwandari, 2017: 23-25).

Implementing the change, the sustainable development model implement the universal development principals, integrative, and inclusive that every individual, cluster, or group participate and enjoy the development in general, as a consequence, the social problems related to poverty, discrepancy, and condition change as an effect of injustice, inequality and imbalance is fundamental area. It's said fundamental as the development must have the universality vision, emphasize the participation of societies (Ishartono and Santoso Tri Raharjo, 2016:164).

Dealing with the above development purpose, SDGs has main program that formulates in five basic principlesto balance the two development aspect, namely social aspect and environmental aspect (Sari, 2016: 180). The above five basic principles are; 1 ) People. This principle qualify to the implementation of global development creating human spirit. The SDGs create the reality of upholding the values of humanity, emancipative, attitude, and honoring toward every rights. 2) Planet, implementing the sustainable development goals, SDGs is not only emphasize to economic improvement but also keep the sustainability of environment, keep the ecosystem and keep the condition change well and sustainable. 3) Prosperity, the principle that emphasize to the reparation of the level of world society life in general, especially the developing countries that has hunger problem, poverty, and imbalance. 4) Peace, the SDGs has necessity participating to create a peace and romance of the world. In this case, the counties that signed the SDGs must participate actively to implement global order which is safe, peace, and harmony. And 5) partnership, strengtheningrelation among countries in the world is a step of making a global partnership which is appropriate one another (Panuluh and MeilaRiskiaFitri, 2016: 6)

Striving to be a success of the development program of SDGs, the above five principles noted in a point of object work. There are 17 purposes and 169 work object of SDGs. If it's compared by MDGs, the number of SDGs work program purpose is more than MDGs which are only 7. The whole SDGs work program purposes are; 1 ) without 
poverty, 2) without hunger, 3) the good health and prosperity, 4) the quality education, 5) gender equality, 6) clean water and sanitation, 7) clean energy and achievable, 8) economic improvement and decent work, 9) innovation industry and infrastructure, 10) reduce the gap, 11 ) sustainability of cities and society, 12) responsible consumption and production, 13) action on condition, 14) underwater life, 15) life on the ground, 16) justice institution and peace, 17) partnership of achieving purpose (Pribadi, 2015: 927).

In the context of Indonesia development, government's commitment of Indonesia toward the agenda of SDGs development noted in the role of president no. 59 year 2017 of implementation of achieving sustainable development purpose, in 4th July 2017 ( Hayati and Muhammad Arif, 2016: 131). Through the role of president, government performs the conciliation of planning of SDGs by development planning with notional long term, 2005-2025 and the development planning national middle term, 2015-2019. The alignment noted in policy draft which is more focus, national planning action and local planning action (Media Indonesia, 27/09/17).

Achieving the above object, SDGs of Indonesia implement developmental system by the principle of No One Will Be Left Behind, the development implementation must give benefit to all element (Fitri, 2016: 9).In addition to the meaning of equity, that the development cannot be centered for one area, but it must be broadcasted and achieving in every area, confirming the development must implement the emancipative spirit and solidarity.The spirit of solidarity qualifies to developmental system which to accommodate importance and society need in general, without debating of social participation or particular gender. Relating to it, developmental approach through emancipative spirit and equity is the implementation of several sustainable developmentalprinciple.

Potential And Challenge Of Madura Tourism Development; A Descriptive Reading

The majority of Indonesia society,address the name of Bangkalan, Sampang, Pamekasan, and Sumenep Regency will not know much. But, addressing the food of Sate Madura, GiliLabakısland, Gili Yang Island, KarapanSapi, Tanianlanjheng, and the art of Pecut Dance, so they imagine Madura Island, the place which is full of various social cultures which upholds religious values.

It is not only known as an area of upholding the normative religious values, but also it is known by various prosperities of social nature. The nature exoticism such as various destinations of tourism in Madura Island that become a purpose of nature lover, traveler and tourist. Such as GiliLabak in Sumenep which is dubbed as The Hidden Paradise, the Gili Yang which has the best oxygen in the world. The hilltop (Puncak Bukit) in Sumenep, the royal court (KeratonKerajaan) in Sumenep, BatuAmpar in Pamekasan, the eternal fire (apiabadi) in Pamekasan, Marthajasah in Bangkalan, the Jeddih hill (Bukit Jeddih) and white cave ( GoaPoteh) in Bangkalan area. 
Besides being rich in nature tourism, Madura has various cultures which are famous the same as other areas in general. Such as the cow race (KarapanSapi), Pecut dance (Taripecut), long yard ( Tanianlanjhen) and other various cultural social values that can be found in local area. The various potentials whether from nature or social culture consist of great selling point that's why it will help improving economic of society and make the Madura to be known by societies. But, achieving that all are not easy. Recognize the prosperity resource of social nature of Madura is not as easy as turning the palm of the hand. Because the process of calculationprogram of tourism is not like the transactional activity in general. Not only focus on the economic improvement, in tourism development project but also focus on the effect of social culture which is exist in the local society. In the point of view of sociology, identifying the social effect of tourism is a difficult thing,it is because of contaminating factors that participate to impact the change occurred (Mathieson and Wall, 1982: 37).

As long as possible, debating of challenging and threatening tourism development are always attached to the external factor. Namely the anxiety of exploitation practice and capitalize the investors. This is to be recognized, in many places of tourism destination development are always followed by capital practices that oriented the profit. The development model like this, in particular limits, potentially have negative effect, and in the practice is always not in the line of development. Never paying attention the layout, and never caring of local wisdom. Analyzing deeply, not only the external problem but also relating to the existence of social culture of local society. In many local tourism developments, everything related to the locality values, in particular limits often become an obstacle of development process of tourism industry.

In the context of Madura tourism development, the locality values is on the hierarchy system of social society that is identically with the patriarchy culture. By hierarchy system, the women as the group society assumed as subordinated, in many occasions have much potential of discriminative treatment. Whether it is in educational social, economic social. Finally they have not occasion for involving in the process of local development actively and sustainably.

As a consequence, anticipating and avoiding the possibilities the challenging and threatening, need to conduct the analysis deeply of the aspect of socio-cultural of Madura society. Especially, dealing with the cultural values and locality values which is in the system and the patriarchy culture. Thus, the conference of development agenda and local tourism improvement of Madura, discussing the importance of supporting of society collective importance, then paying the attention to the discussion of local culture which is directly relating to the gender discussion. The gender discussion is expected to become a solution, in order that the gender problem of Madura tourism development can be accomplished objectively. 


\section{Gender and Madura Tourism Development Problem}

Sociologically, to be able to manipulate the gender problem of Madura women in the dynamic of Madura tourism industry development, it is important to provide the sociology basic question, it means how the Madura women are?.Through this question, at least there are four fundamental issues (Ritzer, 2012: 493). First, the position and the experience of Madura women is not the same as the position and the experience of men at that situation. Second, the position and the experience of women are not only different but also worse or imbalance better than men. Third, the situation which is undergone by the Madura women understood as the practice of men's power. Forth,the treatment of injustice, violence, oppression and inequality are the implementation of their social position diversity in the social order of society.

By the above four prepossession, the gender problem which is affecting Madura women in the dynamic of local tourism development can be classified into four categories; 1) the gender diversity, 2) the gender imbalance, 3) the gender oppression and, 4) the structural oppression. This each categories have the scope, social context, and different perspective theoretic.

\section{The Gender Diversity}

As mentioned earlier, the gender diversity qualify the life reality of women where their position and the experience are not the same with the position and experience of men. In the perspective of contemporary feminism, the typology is occurred by the construction of cultural values of local society. Hence, Ritzer (2012) address that the typology of gender problem is in the cultural feminism area.

In the life of Madura women, the concept of gender diversitycanbe seen by their daily activities, majority the position of women is in the particular place. The time and the participation of women is dominantly for the activity of domestic. While the men have a freedom much time in his participation outdoor.That thing is in the cultural construction of local society which estimates the women by the honoring symbol, moral and reputation. Hence, every obstacle of the reputation women will be considered as abuse of men self-esteem (Wiyata, 2006: 58)

\section{The Gender Imbalance}

The gender imbalance concept as mentioned earlier qualify that the position and the experience of women are not only different but also worse or imbalance better than men. It means the gender imbalance explanation is not only in the equity but also injustice. The injustice is a fulfillment of self-right, such as prosperity, material, freedom, discretion and independence for the career.

Dealing with it, LatifWiyata (2006) finds the fact that the classification of Madura women position cause the bad treatment to them. Namely the social hierarchical forms 
where the men's participation is more dominant in all areas of life.Thus, resulting in excessive treatment of the women.

\section{The Gender Oppression}

The gender oppression is a presupposition of all kinds of situation which is undergone by Madura women for the act of subjugation and the conquest of the men. The situation here refers more to the power practices which in the name of masculinity and femininity. The women's participation are always restrained, crushed, subordinated, and misused.

Ritzer (2012) explains that the gender oppression concept describe the situation that is undergone by the women as the consequence of directly authority relationship of men and women, where the men have the fundamental and concrete necessity for controlling, exploiting and oppressing the women. The whole of subjugation, conquest and coercion are from the domination practice that is implemented in class hierarchical relationship, between men as the subordinated class and women as the super ordinatedclass.

Domination practice in this formsis more to the oppression model that is attached to the tradition, and cultural values, such as patriarchy culture. Hence, the area of gender oppression often occur in the social spaces which is in direct contact with the life of traditional society, where the views of inherited life of the predecessors and the ancestors are maintained, reproduced and conserved simultaneously, so that can influence easily the reality of life society in general.

If it focuses on the above explanation so it can be said gender problem relating to the Madura tourism development industry, majority they are all in this area.Patriarchal tradition as mentioned in sub chapter earlier probably is the most real example, as mentioned earlier the culture of Madura society cannot be separated of patriarchal system. On many occasions, the system has been in a long time created, even intentionally reproduced by the importance and particular purpose.

\section{The Structural Oppression}

The structural oppression has a similarity with gender oppression, namely equally presupposes the injustice treatment, violence, oppression and imbalance which emerged as a form patriarchal culture. Only the gender oppression concerns to the oppression practice which directly related to the subject, so that the concept of cultural oppression more focus on the structure which make the patriarchy itself (Ritzer, 2012: 509).

Thus, the area of this study is more concerned with the existence of regulation, establishment, institution and capitalism practices which are structurally sourced. In this phase, the religious traditional symbol and institution such as Pesantren (Islamic 
Boarding School), Kiai, nyai (schoolars) play the role of their participation and strategic function. The structural positioned itself as, borrowing CliffortGertz's term, cultural broker, where the gender discrimination and dichotomization are always raised.

\section{The Analysis of Marketing Area Strategy of Madura Tourism Industry Through Development Based Gender}

Administratively, Madura is an archipelago listed as part of the eastern province of Java. Unlike most eastern Java areas in general, Madura has typology and characteristic of social nature which is relatively different. Whether in geographically, social culture, until system pattern and social structure of society.Analyzing deeply, we can get the answer that the diversity is as Madura geography which is Maritime area. Many archipelagos are broadcasted in the eastern of Madura, especially administratively noted in Sumenep regency. In Sumenep regency is noted 126 islands.But from all islands, not all inhabited. It is noted only 48 island, for $38 \%$ which are habited. Previously, 78 islands for $62 \%$ are recognized as inhabited islands(Hannan, 2016: 34).

Madura typology as archipelago is not making Madura know as strong area in terms of maritime. In vice versa, in the views of society, Madura is known as an area with hot climates and relatively barren land features. The Madura as barren area is not really true, although in particular areas have that characteristic. With regard to this, the explanation of Hubb De Jonge (1989) about the classification of Madura region can be an answer. The based on his analysis, the Madura social portrait and geographic can be seen by two poles, namely west pole and east pole. West Madura is the Madura has hot typology area with a barren land texture. This west Madura namely Bangklan and Sampang.In vice versa, the east Madura is the Madura area pole has relatively different characteristic. More fertile texture of the land.The potential of plants vegetation, and abundant maritime wealth.Such as salt farming and so on. The east Madura namely two areas Sumenep and Pamekasan regency (De Jonge, 1989: 21).

As mentioned earlier, as one of archipelago area which is rich in the existence of small islands around it, Madura is full of abundant natural potentials. In the term of maritime, Madura can utilize their marine resources as a source of local search and income. There are many economic sectors that can be driven like salt farm, fishery farming and so on. Beyond it all, other things that can be done is utilizing the natural beauty of social Madura as a source of regional development instruments. This instrument here is more to the development and strengthening of the innovation industry sector. One of the innovation that can be offered is by promoting the tourism sector.

As the local developmental instrument, the initiation of innovative industry in Madura through tourism sector, verily has large occasion and potential. Because the Madura is not only rich of values and local creation such as KarapanSapi, TariPecut and 
SapehSonok.But also rich of natural tourist destination, especially the archipelago, beach, and more beautiful natural tourism. They are Gili Yang, that island is known as having the best oxygen in the world. With the original and genuine oxygen, the Gili Yang has big opportunity to become a new tourism destinationwhich will impact the tourist to reach the fresh air. And GiliLabaklsland, the island that has beautiful beach with the white sand which crystallizes. What a beautiful beach of GiliLabak beach the people are called it by The Hidden paradise. In the last two years, the beautiful personal of GiliLabak beach make a thousandtourist, whether local, national, or strange come to this place.

If the social nature potency utilize as optimal as possible, conducting the development process and empowerment intensively and sustainability, then balance it by the infrastructure and good public facility. Then it is not impossible existence of tourism industry of Madura will become the source of the new economic. The existence of the tourism creative industry, in particular limit, directly will implement the economic improvement, society prosperity, and restrain the unemployment as the effect of the work availability for local society.

The fact, although the tourism industry perform a goodness and benefit life of society, the fact, developing and improving it is not the easy thing. Many problems and challenges that must be faced.From the institution, environment even for very basic one.Such as the funding the capital problems. In many cases, the capital problem of tourism improvement are always become scary thing which not least make the perpetrators and stakeholders, government officials are made not move.

Relating to this case, at least the problem of development and tourism industry development can classify into two thing. First, structural problem, this problem focus on the aspect of governance, they have no ability to empower any potentials and the natural wealth of the region. The structural problems can also arise from tourism management that tends to capital. Relating to this, tourism development is stuck on corporate or group interest rather than promoting the public interest collectively. Second, cultural problem. This problem focus on the development problems which the source of social aspect. Especially dealing with the cultural social system of local society, culturally cannot support the agenda of tourism development in local area. In the law of development, cultural social aspect is the most fundamental matter,becausethe problem directly in the reality of the daily life society. In the context of Madura tourism development, one of the main problems is on the cultural system of local society that stuck on hierarchical system, especially the gender problem which is from the patriarchal culture.

Theoretically, the developmental principle must emphasize the universality, emancipation, and equation. The development agenda, including tourism sector, imbalanced by the three principles, it will occur the imbalance. They are as the high 
social class, it will create the domination. In the practice, every dominative, whether in the authority, social class, or the particular participation, will have the imbalance and every discriminative biases.Finally, the most negative impact is not only make the society undergo the subordinating but also hide them to involve directly to the local development. Inability region create the emancipative development system based the gender equality and justice finally became an obstacle.The top of all are the failure develop the branding of tourism marketing, whether in local level, regional, national, or international.

Dealing with this, Richard Florida (1957) address the agenda of development and innovative industry improvement can run well through three factors, contracted as 3T, namely Talent, Technology, and Tolerance (Leksono, 2014: 2). The talent factor symbolize the attendance of human resources infestation which is educated and trained having a health learning culture, and the most is having enough education background, great and qualified. Whether the scientific education, technology, character, and art and culture. The most crucial of this aspect, the strengthening of talent must be broadcasted to the whole element of society without exception. Whether high class society or low class society, men or women. Theoretically, the people with the talent and high education, they will more ready to face the change and will equip with extensive knowledge, so it can be competitive in global competition.

The technology become second factor which determines local marketing process, including development of tourism innovative industry. The mastery of technology will impact significantly to the availability of technology infrastructure, thus triggering the ability of regional innovation. Efficient public service and digital public service will really support the promotion of the region. In this case, we are able to learn a success of Banyuwagi regency which is success to develop its regional tourism through their ability utilizing the technology as a medium to promote their tourism area.

The last factor besides the talent and technology, the agenda of marketing local tourism according to Richard Florida (1957) is tolerance. The tolerance qualify the group or certain group of people for living with other people with a peace.Thereadiness of living together to respect each other, affection, respect and uphold the equity and justice. The equity principle is not only relating to the social class, but also social participation between men and women. Tolerance means aware whether in thinking, attitude and action to be always justice and uphold the equity. The agenda of tourism development then the development of physical and also the development of mentality and culture. In this perspective the area with the spirit of tolerance culture is guaranteed to have a pleasure, peace, and composure for every tourist which come to the place.

\section{CONCLUSION}


Madura is the archipelago that has source of abundant social wealth, from the western of Madura namely Bangkalan until the eastern of Madura namely Sumenp. In social sector, the wealth of Madura in on the local creativity values, such as KarapanSapi, TariPecut, SapehSonok, and so on. In the natural sector, Madura has destination ofnaturalbeautythat broadcasted in several islands. NamelyLabak beach in GliLabaklsland, Pantai Sembilan in Gili Yang. A whole spill of social wealth has great potential to be empowered as an innovative industry in the form of tourism.

To realize the Madura tourism industry is needed the marketing strategy which is not only good but also effective. The good and effective marketing strategy directly will attract tourist market share, finally, it will support the local area popularity of Madura as the destination of traveler. Whether local or international traveler. In the views of Richard Florida, develop the good and effective industry area marketing strategy must by three strategic steps, that mentioned by him as 3T. The three of them are Talent, Technology, and Tolerance.

The Colum talent of society that the development of Madura tourism industry must be started earlier repairing in the sector of human resources collectively and completely. Encouraging the Madura society become more educated and trained. Having the health learning culture, and the most crucial is having enough education background so it can be competitive in global competition. While the Colum technology of society qualify to the mastery of technology and current information media. The mastery and the use of technology directly will really help whether in the process of development and area marketing of tourism industry all over the Madura. And the most crucial among the above two points is tolerance. Relating to the process of area marketing of tourism industry, the society's tolerance to have a will to uphold the human right and basis, giving the priority of the spirit of justice and equity, without differentiating the high social class and the low social class society, between men and women.

\section{REFERENCES}

,(2001). KamusBesarBahasa Indonesia. Jakarta: BalaiPustaka.

Anggraini, Amelia. (2017). Indonesia dan SDGS, http://www.mediaindonesia.com/, 27 sep 2017.

Bambang S, E. (2004). Otonomi Daerah Masih Mengesampingkan Peran Perempuan. Jurnal Perempuan. Vol. 2 (4).

Darsyah, M. Y., \& Wasono, R. (2013). Pendugaan Tingkat Kemiskinan di Kabupaten Sumenep dengan Pendekatan SAE. PROSIDING SEMINAR NASIONAL \& INTERNASIONAL (Vol. 1, No. 1).

Erwandari, N. (2017). Implementasi Sustainable Development Goals (SDGs) Dalam 
The Marketing Strategy of Madura Tourism Industry Area Trough...

Meningkatkan Ketahanan Pangan Di Provinsi Riau. Jurnal Ilmu Hubungan Internasional, 5(3).

Fitria, T. N. (2016). Kontribusi Ekonomi Islam Dalam Pembangunan Ekonomi Nasional. Jurnal IImiah Ekonomi Islam, 2(03).

Hendriyani, C. (2016). Contradictions Economic Growth\& Investor Exit in Indonesia. AdBispreneur, 1(1).

King, E., \& Mason, A. (2001). Engendering Development: Through Gender Equality In rights, resources, and voice. The World Bank.

Leksono, A., \& Santosa, P. B. (2013). Faktor-Faktor Yang Mempengaruhi Pendapatan Industri Kreatif Di Indonesia (Tahun 2002-2008) (Doctoral dissertation, Fakultas Ekonomika dan Bisnis).

Mathieson, A., \& Wall, G. (1982). Tourism, economic, physical and social impacts. Longman.

Nugroho, I., \& Dahuri, R. (2004). Pembangunan Wilayah: Perspektif Ekonomi, Sosial, Dan Lingkungan. LP3ES.

Panuluh, Sekar \& Meila Riskia Fitri. (2016). Perkembangan Pelaksanaan Sustainable Development Goals (Sdgs) Di Indonesia September 2015-September 2016. Paper dalam International NGO Forum On Indonesian Development.

Pasaribu, R. B. T. th. Teori-Teori Pembangunan. Tanpa penerbit.

Prasetya, D. M. (2017). Geopolitik Bantuan Luar Negeri Dari Perang Dingin Sampai Globalisasi. Jurnal Sosial Politik, 2(1), 16-28.

Pitana, I. G., \& Gayatri, P. G. (2005). Sosiologi pariwisata. Yogyakarta.

Pustaka, B. (2001). Kamus Besar Bahasa Indonesia. Jakarta: Balai Pustaka.

Raharjo, S. T. (2016). Sustainable Development Goals (SDGs) dan Pengentasan Kemiskinan. SHARE: Social Work Journal, 6(2).

Rahadian, A. H. (2016, February). Strategi pembangunan berkelanjutan. In Prosiding Seminar STIAMI (Vol. 3, No. 1, pp. 46-56).

Ritzer, G., \& Goodman, D. J. (2004). Teori Sosiologi Klasik sampai Post Modern.

Restiyanto, D. T., \& Yusroni, N. (2006). Kegagalan Pembangunan Ekonomi Indonesia Akibat Terperangkap Kegagalan Pendekatan Teori Ekonomi Pembangunan. AKSES: Jurnal Ekonomi dan Bisnis, Vol 1(2). 
Sulistyastuti, D. R. (2007). PEMBANGUNAN PENDIDIKAN DAN MDGs DI INDONESIA Sebuah Refleksi Kritis. Jurnal Kependudukan Indonesia, 2(2), 19-44.

Surtikanti. (2013).Permasalahan Otonomi Daerah Ditinjau Dari Aspek Perimbangan Keuangan Pemerintah Pusat Dan Daerah. Majalah IImiah Unikom, Vol. II (1).

Susanto, N. H. (2015). Tantangan Mewujudkan Kesetaraan Gender Dalam Budaya Patriarki. Jurnal Muwazzah, 7(2).

Sutarso, J. (2017). Konstruksi Isu Gender Dalam Politik: Studi Kasus Pemilihan Umum 2004. Komuniti: Jurnal Komunikasi dan Teknologi Informasi, 2(2), 3-13.

Tikson, D. T. (2005). Keterbelakangan \& Ketergantungan: Teori Pembangunan Di Indonesia, Malaysia, dan Thailand. Ininnawa.

Utomo, B. (2007). Tantangan Pencapaian Millenium Development Goals (MDGs) Bidang Kesehatan di Indonesia. Kesmas: National Public Health Journal, 1(5), 232-240.

Wirartha, I. M. (2006). Metodologi Penelitian Sosial Ekonomi. Yogyakarta: CV Andi Offset.

Wirawan, R., \& Nurpratiwi, R. (2015). Partisipasi masyarakat dalam perencanaan pembangunan daerah. JISIP: Jurnal IImu Sosial Dan IImu Politik, 4(2).

Wiyata, A. L. (2003). Madura yang Patuh?; Kajian Antropologi Mengenai Budaya Madura. 